\title{
Stiffness degree of ankle range of motion in diabetic patients with atypical amputation
}

\author{
(iD) Eduardo Simón-Pérez ${ }^{1}$ \\ (iD) Clarisa Simón-Pérez² \\ (iD) David Alonso-Peña ${ }^{3}$ \\ (DD) Alejandro Pontón-Cortina ${ }^{4}$ \\ (iD) Esther Chicharro-Luna ${ }^{5}$ \\ (iD) Alfonso Martínez-Nova ${ }^{6}$ \\ (iD) Emmanuel Navarro-Flores ${ }^{7}$
}

\begin{abstract}
1. DP Recoletas Felipe II Hospital C/ Felipe II, 947003 , Valladolid, Spain 2. Traumatology and Orthopedic Surgery Service, Clinical University Hospital Valladolid. Av. Ramón y Cajal, 3, 47003 - Valladolid. Spain.

3. Plastic Surgery Service. University Hospital "Río Hortega" Calle Dulzaina, 2, 47012 - Valladolid. Spain.

4. Cardiovascular Service Marqués de Valdecilla Hospital. Av. Valdecilla, 25, 39008 - Santander. Spain. 5. DP University Miguel Hernández. Health and Behavioral Science Department. Faculty of Medicine. 03550 San Juan de Alicante. Spain. 6. Nursing Department. University of Extremadura. Avenida Virgen del Puerto 2, 10600 - Plasencia, Cáceres, Spain. 7. DP Research Group FROG: Cognitive Deterioration and Frailty, Nursing Department, Faculty of Nursing and Podiatry, University of Valencia, 46001 - Valencia, Spain.
\end{abstract}

http://dx.doi.org/10.1590/1806-9282.66.2.216

\section{SUMMARY}

In diabetics, foot deformities are risk factors that increase the risk of amputation as a result of developing ulcers. However, knowledge of the influence of plantar stiffness is still limited. The main objective was to describe connections between the degree of stiffness of the ankle, atypical amputation, and the Foot Posture Index (FPI).

METHODS: 62 diabetic patients, 58 with type 2 and 4 with type 1 (average age 63.35 years) were included. Records of foot deformities were included; A range of motion test of the ankle joint was used to determine the degree of stiffness. An exploratory analysis of the association of foot position and the degree of rigidity was performed.

RESULTS: The dorsal flexion range of the ankle was $9.6 \pm 5.1^{\circ}, 13.8 \pm 5.9^{\circ}$ and $17.2 \pm 6.5^{\circ}$ and $20.5 \pm 6.8^{\circ}$ to $45,67,89$ and $111 \mathrm{~N}$ respectively in the amputated feet., And 14 patients (22.58\%) had a high level of pronation of IPF with an average value of $3.7 \pm 2.629, \mathrm{Cl}$ (3.032.-4.367) in amputated feet compared to non-amputees. We use the device "Iowa ankle range of motion" (IAROM) to determine the differences in ankle stiffness. Proper IPF was associated with the presence of amputation and an increase in stiffness

CONCLUSIONS: There was an increase in the degree of limitation of movement of the ankle, as a greater force was applied. Comparing FPI between the groups, there was a higher frequency of prone feet in the group of amputees

KEYWORDS: Diabetic foot. Risk factors. Amputation. Ankle joint/physiopathology.

\section{INTRODUCTION}

The presence of minor amputations in patients with diabetes mellitus (DM) is a consequence of failed preventive measures to avoid this complication ${ }^{1}$. Plantar stiffness associated with amputation has consequences on feet posture, causing deformities that are more present in diabetic individuals ${ }^{2}$. The measurement of the FPI to determine the posture of the foot is a test that should be considered 
since feet in the prone position have more risk of ulceration ${ }^{3}$.

Amputations can be classified as major (foot, leg or thigh) or minor (toe, metatarsals) ${ }^{4}$.

Major amputations involve disability and mortality and generate expenses from your medical care ${ }^{5.6}$. It is important to consider that, in the USA, the costs generated by the amputation of diabetic feet range between 30,000 and 60,000 dollars.

Minor amputations also have repercussions, since even the loss of intermediaries toes (2nd, 3rd, 4th) causes functional and biomechanical problems ${ }^{7}$. For this reason, nowadays, to preserve the maximum bone length and obtain a better functional outcome, atypical amputations are performed, which by various strategies attempt to preserve the maximum tissue possible in the foot ${ }^{8}$.

Plantar stiffness does not appear in diabetic patients with neuropathy, but in cases with ulcers. That is why early detection of rigidity could prevent the emergence of future complications ${ }^{9}$.

Studies conducted to date to determine the classification of stiffness of movement at the ankle joint in patients with atypical distal amputation have focused mainly in the Goniometric measurement of the classification of joint movements that the patient is able to perform, leaving aside the degree of stiffness as a physical concept, as disregarding the FPI as a method for the clinical classification of the foot position, which can contribute as a determinant for predicted complication factors ${ }^{10}$.

If we also consider that the comparison with the contralateral limb, race, when used, there are circumstances to justify our research, in which we present the results of a study conducted to determine the influence of ankle stiffness in patients with atypical distal amputation regarding the position of the foot ${ }^{10.11}$.

This is an observational, descriptive, cross-sectional study on patients who underwent atypical distal amputation of one of their feet due to diabetes complications.

\section{OBJECTIVE}

Compare the classification of ankle joint movement of patients who underwent atypical distal amputation, with those that were not amputated to determine if there are any differences of rigidity and in FPI.

Assess changes in the pattern of foot posture in patients with atypical distal amputations.

\section{METHODS}

We present the results of an observational, descriptive, cross-sectional study on patients who underwent atypical distal amputation of one of their feet due to diabetes complications. This is based on 2 searches of the Angiology and Vascular Surgery Service at the University Hospital of Valdecilla Santander (Spain) and the Diabetic Foot Unit of the Endocrinology Service at the Hospital Athan Trias i Puyol, Catalonia (Spain), between January 2016 and October 2017. The measurements were recorded by a team, including a physician specialized in cardiovascular surgery, one specialized in plastic surgery, and a podiatrist, all with over 10 years of experience in the treatment of diabetic patients.

We requested approval from the Research Ethics Committee of the University of Extremadura, under Registration No. 84/2016. In addition, we respected the rights of patients pursuant to the ethical standards of the Declaration of Helsinki, and their personal data was protected by the organic law (15/1999).

For inclusion in the present study, patients had to be over 18 years and of both sexes, with DM type 1 or 2 , the presence of neuropathy, and diabetic foot ulcer in advance, and with atypical unilateral forefoot amputation after at least one year of follow-up, which, at the time of measurement, showed ulceration in neither feet, without ischemia of the lower limbs, without the presence of limiting cognitive or functional impairment, such as of locomotion to participate in the study and had to agreed to participate in the study by means of informed consent.

Patients were excluded if they had Charcot foot or general signs related to systemic infection. Pregnant women or with suspicion of pregnancy were also excluded.

\section{Sample characteristics}

The sample included 62 subjects, of which 50 were men $(80.6 \%)$ and $12(19.4 \%)$ women. The average age of patients was $60.2 \pm 8.5$ years, with a height of 172.32 $\pm 7.9 \mathrm{~cm}$, weight of $84.16 \pm 9.95 \mathrm{~kg}$, and BMI of 28.33 \pm 3.7 . The average feet figure was $42.32 \pm 2.23 \mathrm{~cm}$. The average glycated hemoglobin (HbA1C) value was $7.060 \pm 0.946 \%$

\section{Evaluation of ankle stiffness}

To measure the classification of ankle movement, we used the IAROM validated measuring system ${ }^{12}$. This device is mainly composed of two methacrylate 


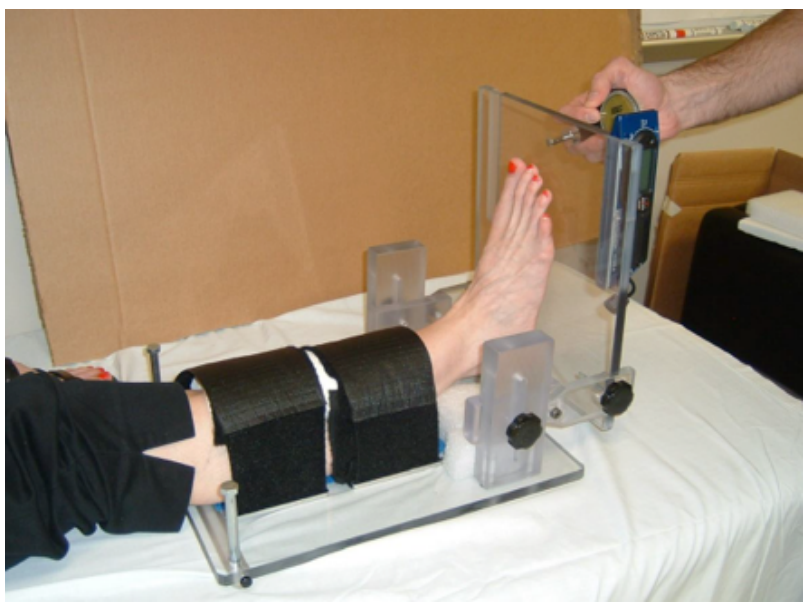

panels bound by a mobile axis, which coincides with the ankle joint. The is placed in this device and secured with a band to make sure only pure movements of dorsal and plantar flexing are allowed by the ankle joint. (Image 1.)

To secure the foot, we used some velcro straps. We had the help of a digital magnetic inclinometer to measure the precise angle at the exact moment the prescribed force is applied.

To apply a known force and with good reproducibility, we had the help of a penetrometer (Wagner Force FDK Dial - 40). Thus, the force applied in all assessments was as accurate as possible ${ }^{13}$.

All patients were placed in the supine position with the knee extended at the time of the assessment test for the classification of ankle movement.

We measured the articular classification of the movement of the ankle joint of the lower limb that underwent atypical distal amputation and the contralateral limb (without amputation).

The forces applied with the penetrometer were the following: 45, 67, 89, and $111 \mathrm{~N}$. Three measurements

TABLE 1. SOCIO DEMOGRAPHIC CHARACTERISTICS ACCORDING TO SEX

\begin{tabular}{l|l} 
& $\begin{array}{l}\text { Total }(\mathrm{N}=62) \\
\text { Men }(\mathrm{n}=50) \\
\text { Women }(\mathrm{n}=12) \\
\text { Mean } \pm \mathrm{SD}(95 \% \mathrm{Cl})\end{array}$ \\
\hline Age (years) & $63.35 . \pm 8.495(61.342-65.657)$ \\
\hline Weight $(\mathrm{kg})$ & $84.16 \pm 12.229(81.054-87.265)$ \\
\hline Height $(\mathrm{m})$ & $172.32 \pm 7.981(170.293-174.346)$ \\
\hline BMI & $28.33 \pm 3.704(27.389-29.270)$ \\
\hline HbA1C $(\%)$ & $7.060 \pm 0.946(6.797-7.334)$ \\
\hline
\end{tabular}

Abbreviations: SD: standard deviation; kg: kilogram; m: meters; BMI: Body Mass Index; Mean Glycosylated hemoglobin (HbA1C); IC95\%: confidence interval at 95\%; Statistical significance for a value of $p<0.05$, with a confidence interval of $95 \%$.

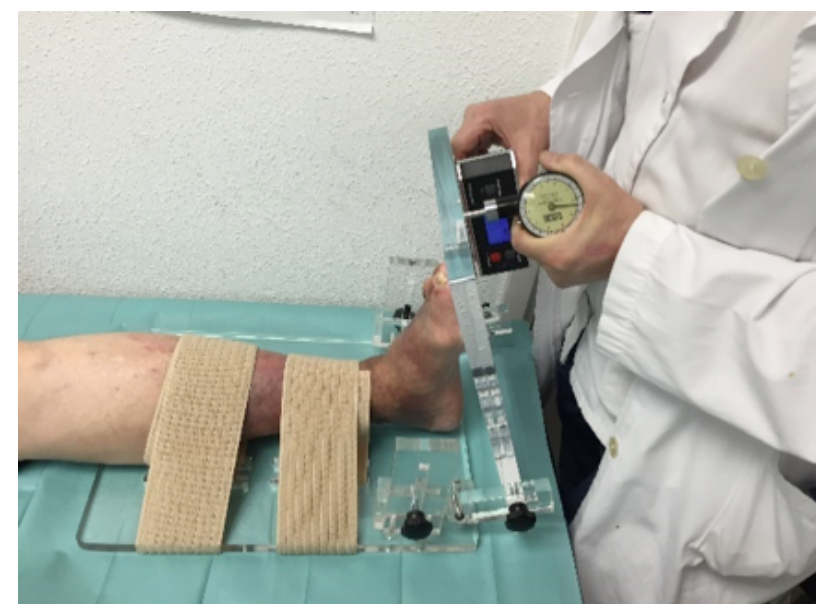

were performed for each applied force, recording them for statistical analysis.

\section{Assessment of foot posture index}

The measurement of the FPI was performed according to the criteria by Redmond et al. ${ }^{14}$. Patients were asked to stand, relaxed, and with bipodal support (with their arms relaxed on each side and looking forward).

\section{RESULTS}

The sample included 62 subjects, of which 50 were men (80.6\%) and 12 (19.4\%) women. In addition, we collected demographic data (age, sex, weight, size, and body mass index), and the FPI.

All variables were treated by the normality of distribution using the Kolmogorov-Smirnov test, and the data were considered normally distributed if $p>0.05$.

The independent Student t-tests were calculated to determine if the differences were statistically significant when there was a normal distribution. (Table 1)

To determine the indexes of foot posture, we performed a descriptive analysis, expressed in the form of mean \pm standard deviation. To determine the differences between the amputated foot and its contralateral, we used the parametric Student t-test for paired samples.

The value of global FPI for the amputated feet was $3.7 \pm 2.6$, while the non-amputated was $3.1 \pm 3$.4. The Student $\mathrm{t}$-test for paired sample indicates the differences were not significant $(\mathrm{p}=0.221)$.

The joint classification of dorsal flexion of the ankle was $9.6 \pm 5.1^{\circ}, 13.8 \pm 5.9^{\circ}$ and $17.2 \pm 6.5^{\circ}$ and $20.5 \pm 6.8^{\circ}$ at $45,67,89$, and $111 \mathrm{~N}$, respectively, in 
TABLE 2. FPI CHARACTERISTICS AND ANKLE DEGREE OF FD IN UMPUTATED AND NONAMPUTATED PATIENTS

\begin{tabular}{l|l|l|l}
\hline Variable & $\begin{array}{l}\text { Amputated }(\mathrm{n}=62) \\
\text { Mean } \pm \text { SD }(95 \% \mathrm{Cl})\end{array}$ & $\begin{array}{l}\text { Non-Amputated }(\mathrm{n}=62) \\
\text { Mean } \pm \text { SD }(95 \% \mathrm{Cl})\end{array}$ & $\begin{array}{l}\text { P-value/ Amputated vs } \\
\text { Non-amputated }(\mathrm{n}=62)\end{array}$ \\
\hline $\begin{array}{l}\text { FPI } \\
\text { Value 0-6) }\end{array}$ & $\begin{array}{l}3.7 \pm 2.629 \\
(3.032 .-4.367)\end{array}$ & $\begin{array}{l}3.1 \pm 3,446 \\
(2.224 .-3.975)\end{array}$ & 0.221 \\
\hline $\begin{array}{l}\text { Strength 45N } \\
\text { Ankle FD degrees }\end{array}$ & $\begin{array}{l}9.689 \pm 5.183 \\
(8.372 .-11.005)\end{array}$ & $\begin{array}{l}12.060 \pm 5.206 \\
(1.737 .-13.382)\end{array}$ & 0.001 \\
\hline $\begin{array}{l}\text { Strength 67 N } \\
\text { Ankle FD degrees }\end{array}$ & $\begin{array}{l}13,885 \pm 5,957 \\
(12.372 .-15.397)\end{array}$ & $\begin{array}{l}16,941 \pm 5,846 \\
(15.456 .-18.425)\end{array}$ & 0,001 \\
\hline $\begin{array}{l}\text { Strength 89 N } \\
\text { Ankle FD degrees }\end{array}$ & $\begin{array}{l}17,206 \pm 6,512 \\
(15.552 .-18.859)\end{array}$ & $\begin{array}{l}20,436 \pm 6,311 \\
(18.333 .-20.038)\end{array}$ & 0,001 \\
\hline $\begin{array}{l}\text { Strength 111 N } \\
\text { Ankle FD degrees }\end{array}$ & $\begin{array}{l}22.55 \pm 6,882 \\
(18.802 .-22.297)\end{array}$ & $\begin{array}{l}23.688 \pm 6.431 \\
(22.034 .-25.301)\end{array}$ & 0.001 \\
\hline
\end{tabular}

Abbreviations: SD, standard deviation; 95\% Cl, confidence interval at 95\%; FPI ( Foot posture Index). Statistical significance for a value of $p<0.05$, with a confidence interval of $95 \%$.

TABLE 3. CORRELATION BETWEEN HBATC AND THE DEGREES OF ANKLE DORSAL FLEXING

\begin{tabular}{l|l|l}
\hline $\begin{array}{l}\text { Variable } \\
\text { Stiffness }\end{array}$ & $\begin{array}{l}\text { Amputated }(\mathrm{n}=62) \\
\text { R HbA1c and ankle FD degrees }\end{array}$ & $\begin{array}{l}\text { P-value } \\
(\mathrm{n}=62)\end{array}$ \\
\hline Strength 45N & -0.240 & 0.439 \\
\hline Strength 67 N & -0.199 & 0.235 \\
\hline Strength $89 \mathrm{~N}$ & -0.219 & 0.100 \\
\hline Strength $111 \mathrm{~N}$ & -0.230 & 0.132 \\
\hline
\end{tabular}

Abbreviations: HbA1C Mean Glycated Hemoglobin, Statistical significance for a value of $p<0.05$, with a confidence interval of $95 \%$.

the amputated legs. The contralateral feet presented a classification of greater movement $\left( \pm 3^{\circ}\right.$ approx.) in all the forces applied ( $\mathrm{p}=0.001$ in all cases)

Comparing the frequencies of FPO between the amputated and not amputated feet, we found a higher frequency of feet in the prone position in the group of amputees ( $\mathrm{p}=0.001)$. (Table 2 and 3 )

The statistical analysis was performed using SPSS v. 19.0 (SPSS, Chicago, IL)

\section{DISCUSSION}

Although demonstrated the first time in the hand ${ }^{15}$, the limitation of mobility because of diabetes has been studied in multiple studies at the level of the foot and ankle ${ }^{16-18}$.

The results show a position approximately one point more prone than in regular non-amputated individuals, but still within the parameters of a neutral foot (0 to 5$)^{19}$.

This finding is of great interest since feet in the prone position have an increased risk of ulceration, and, in our study, there is a higher frequency of feet in the prone position in the group of amputees ${ }^{3}$.
The limitation of mobility in joints such as the tarsal was related to increased pressure in the metatarsal zone $^{20}$, which leads us to think that the stiffness may have significant consequences on joints such as the ankle, which, as we know, needs a classification of motion in joint from $12^{\circ}$ of dorsal flexing during the support phase to $9^{\circ}$ of plantar flexing at the start of the balancing phase to develop a physiological gait ${ }^{21}$.

Rao et al. ${ }^{18}$ compared ankle stiffness between patients with and without diabetes and demonstrated that diabetic patients had more stiffness in the ankle. Another study by the same author also concluded there was reduced mobility in the frontal plane of the calcaneal, which reduced flexibility in patients with diabetes mellitus compared with healthy patients ${ }^{19}$. In our sample, both feet behaved differently, since the classification of dorsal flexing movement of the ankle is up to 3 degrees higher in the non-amputated foot.

In our study, neither age, nor smoking, nor the BMI, nor Hb1Ac influenced the classification of ankle stiffness, in contrast to the non-enzymatic glycosylation phenomenon studied, which affects the body of diabetic patients and its relationship with the elasticity of tissues ${ }^{22}$. 
On the other hand, the results from Rao et al..$^{13}$ showed that people with diabetes mellitus had significantly lower dorsiflexion (between 5.1 and 11.5 degrees) and greater ankle stiffness (0,016 and 0,008 $\mathrm{Nm} / \mathrm{kg} /$ degree) than non-diabetic individuals. In patients with diabetes mellitus, there was a positive relationship between glycemic control and the duration of diabetes mellitus and ankle stiffness, respectively; in our study, we did not find any correlation between these aspects.

\section{CONCLUSIONS}

Feet with atypical distal amputations feature classification of dorsal flexing movement in the ankle lower than the contralateral foot.

Amputated feet have a tendency of FPI in the prone position, as does the contralateral foot.

\section{LIMITATIONS}

In our study, all patients were white, which could be a factor to consider for further studies, since another study has found greater joint restriction in white diabetic patients than in African-Americans ${ }^{23}$.

"All authors certify that we have participated substantially in the conception, design, analysis, and writing of this study, and we have approved the manuscript and agree with its submission to RAMB. This manuscript represents original, unpublished material and is not under consideration for publication elsewhere, nor has it been posted on the Internet for public access.

Contributorship statement: ENF in conceived and designed the study section and also in analyzed and interpreted the data may include ENF finally in draftead manuscript section must appears ENF.

\section{RESUMO}

Nos diabéticos, as enfermidades nos pés são fatores de risco, que aumentam o risco de sofrerem uma amputação, como resultado do desenvolvimento de úlceras. Contudo, o conhecimento sobre a influência da rigidez plantar ainda é limitado. O objetivo principal foi descrever conexões entre o grau de rigidez do tornozelo, a amputação atípica e o Foot Posture Index (FPI).

MÉTODos: 62 diabéticos, 58 com tipo 2; e 4 com tipo 1 (idade média de 63.35 anos). Incluindo o registro de deformidades do pé; teste de classificação do movimento da articulação do tornozelo, para determinar o grau de rigidez. Realizou-se uma análise exploratória da associação da posição do pé com o grau de rigidez.

RESULTADO: A classificação de flexão dorsal do tornozelo foi de $9.6 \pm 5.1^{\circ}, 13.8 \pm 5.9^{\circ}$ e de $17.2 \pm 6.5^{\circ}$ e $20.5 \pm 6.8^{\circ}$ a $45,67,89$ e $111 \mathrm{~N}$ respectivamente nos pés amputados, e 14 pacientes (22.58\%) teve alto nível de pronação de $\mathrm{FPI}$ com um valor médio de $3.7 \pm 2.629$, IC(3.032.-4.367) em pés amputados com relação aos não amputados. Utilizamos o dispositivo "lowa ankle range of motion" (IAROM) para determinar as diferenças de rigidez do tornozelo. O FPI pronado foi associado à presença de amputação e um aumento da rigidez. CONCLUSÕES: Aumento do grau de limitação do movimento do tornozelo; à medida que se aplicava uma força maior. Comparando FPI entre os grupos existentes maior frequência de pés pronados no grupo de amputados.

PALAVRAS-ChaVe: Pé diabético. Fatores de risco. Amputação. Articulação do tornozelo/fisiopatologia.

\section{REFERENCES}

1. Organización Mundial de la Salud. Informe mundial sobre la diabetes. Geneve: Organización Mundial de la Salud; 2016.

2. Estévez Perera A, García García Y, Licea Puig ME, Fundora AA, Álvarez Delgado $\mathrm{H}$. Identificación de las deformidades podálicas en personas con diabetes mellitus, una estrategia para prevenir amputaciones. Rev Cubana Endocrinol. 2013;24(3):297-313.

3. Molines-Barroso RJ, Lázaro-Martínez JL, Aragón-Sánchez FJ, Álvaro-Afonso F), García-Morales E, García-Álvarez Y. Forefoot ulcer risk is associated with foot type in patients with diabetes and neuropathy. Diabetes Res Clin Pract. 2016;114:93-8.

4. Costa RHR, Cardoso NA, Procópio RJ, Navarro TP, Dardik A, Loiola Cisneros L. Diabetic foot ulcer carries high amputation and mortality rates, particularly in the presence of advanced age, peripheral artery disease and anemia. Diabetes Metab Syndr. 2017;11(Suppl 2):S583-7.

5. Cisneros-González N, Ascencio-Montiel IJ, Libreros-Bango VN, Rodriguez-Vázquez H, Campos-Hernández Á, Dávila-Torres |, et al. Lower extremity amputation rates in diabetic patients. Rev Med Inst Mex Seguro Soc. 2016;54(4):472-9.

6. Cefalu WT. American Diabetes Association Standards of Medical Care in Diabetes 2017. | Clin Appl Res Educ. 2017;40(1):95-102.

7. Caravaggi $C$, Sganzaroli $A$, Galenda P, Bassetti M, Ferraresi R, Gabrielli L. The management of the infected diabetic foot. Curr Diabetes Rev. 2013;9(1):7-24.

8. Attinger $C$, Venturi M, Kim K, Ribiero C. Maximizing length and optimizing biomechanics in foot amputations by avoiding cookbook recipes for amputation. Semin Vasc Surg. 2003;16(1):44-66.

9. Searle A, Spink MJ, Ho A, Chuter VH. Association between ankle equinus and plantar pressures in people with diabetes. A systematic review and meta-analysis. Clin Biomech (Bristol, Avon). 2017;43:8-14

10. Tang UH, Zügner R, Lisovskaja V, Karlsson |, Hagberg K, Tranberg R. Foot deformities, function in the lower extremities, and plantar pressure in patients with diabetes at high risk to develop foot ulcers. Diabet Foot Ankle. 2015;6:27593. 
11. Cerrahoglu L, Koşan U, Sirin TC, Ulusoy A. Range of motion and plantar pressure evaluation for the effects of self-care foot exercises on diabetic patients with and without neuropathy. I Am Podiatr Med Assoc. 2016;106(3):189-200.

12. Wilken |, Rao S, Estin M, Saltzman C, Yack HI. A new device for assessing ankle dorsiflexion motion: reliability and validity. J Orthop Sport Phys Ther 2011;41(4):274-80.

13. Rao SR, Saltzman CL, Wilken J, Yak HJ. Increased passive ankle stiffness and reduced dorsiflexion range of motion in individuals with diabetes mellitus. Foot Ankle Int. 2006;27(8):617-22.

14. Redmond AC, Crosbie J, Ouvrier RA. Development and validation of a nove rating system for scoring standing foot posture: the Foot Posture Index. Clin Biomech (Bristol, Avon). 2006;21(1):89-98.

15. Rosenbloom AL, Silverstein JH, Lezotte DC, Richardson K, McCallum M Limited joint mobility in childhood diabetes mellitus indicates increased risk for microvascular disease. N Engl | Med. 1981;305(4):191-4.

16. Bryant A, Tinley P, Singer K. Radiographic measurements and plantar pressure distribution in normal, hallux valgus and hallux limitus feet. Foot. 2000;10(1):18-22.

17. Birke JA, Cornwall MW, Jackson M. Relationship between hallux limitus and ulceration of the great toe. J Orthop Sports Phys Ther. 1988;10(5):172-6.

18. Rao S, Saltzman C, Yack HI. Ankle ROM and stiffness measured at rest and during gait in individuals with and without diabetic sensory neuropathy. Gait Posture. 2006;24(3):295-301.

19. Rao S, Saltzman CL, Yack HJ. Relationships between segmental foot mobility and plantar loading in individuals with and without diabetes and neuropathy. Gait Posture. 2010;31(2):251-5.

20. Fernando DI, Masson EA, Veves A, Boulton A|. Relationship of limited joint mobility to abnormal foot pressures and diabetic foot ulceration. Diabetes Care. 1991;14(1):8-11.

21. Matjačić $Z$, Olenšek $A$, Bajd T. Biomechanical characterization and clinical implications of artificially induced toe-walking: differences between pure soleus, pure gastrocnemius and combination of soleus and gastrocnemius contractures. J Biomech. 2006;39(2):255-66.

22. Gutnik B, Skurvydas A, Zuoza A, Zuoziene I, Mickevičnienė D, Alekrinskis A et al. Evaluation of bilateral asymmetry between upper limb masses in righthanded young adults of both sexes. Percept Mot Skills. 2015;120(3):804-15.

23. Veves A, Sarnow MR, Giurini IM, Rosenblum BI, Lyons TE, Chrzan IS, et al, Differences in joint mobility and foot pressures between black and white diabetic patients. Diabet Med. 1995;12(7):585-9. 